\title{
Identifying The Relationship Between Motivation, Anxiety and Intended Effort of Learning English: An SEM Approach
}

\author{
$1^{\text {st }}$ Yovan Pino Putra ${ }^{1}, 2^{\text {nd }}$ Rosalie Ariel Hall ${ }^{2}$ \\ \{yovan@totalmindlearning.com ${ }^{1}$, rosaliearielhall@gmail.com ${ }^{2}$ \} \\ Universitas Negeri Jakarta, Indonesia ${ }^{1}$, University of York ${ }^{2}$
}

\begin{abstract}
South Bengkulu Dept. of Education in 2017 initiated English Community Learning Program (PPKBI), addressed to all high school students in South Bengkulu Regency. As the program progresses, students' learning motivation tends to dissipate, seen from the decreasing number of participants. This study aims to identify the relationship between motivation, anxiety and intended effort in learning English.This study uses data from 453 high school students in South Bengkulu Regency, participants of PPKBI 2017 (average 16.15 years, 179 female).The questionnaires consisted of 40 items (LLOS / Language Learning Orientation Scale (24 items), Foreign Language Class Anxiety Scale (6 items) and Intended Effort (10 items). Analysis done by identifying common factors using Exploratory Factor Analysis, followed with Confirmatory Factor Analysis (CFA).The hypothesized model fulfills the requirement of goodness of fit index and questionnaires have good validity and reliability indexes. The model explains that most students who follow through with PPKBI are more intrinsically motivated.
\end{abstract}

Keywords: Motivation, English Learning, Anxiety, Intended Effort, EFA, CFA

\section{Introduction}

\subsection{Background}

Recent study results still indicate that Indonesian high school students' English mastery is relatively low compared to that of students from neighboring countries, rank 34 of 44 countries assessed[1].

In an effortto improve English skills specifically for high school students the Government of South Bengkulu Regency initiated a breakthrough by starting the English Community Learning Program (Program Pembelajaran Komunitas Bahasa Inggris / PPKBI in 2017)[2]. PPKBI instructors, consisting of both local and international English teachers, were brought in from Jakarta.

As the program progressed, a noticeable change in the motivation and learning of students took place.

\subsection{Motivation for Learning Foreign Languages}


There are three main types of motivation: amotivation, extrinsic and intrinsic motivation[3]. These motivational orientations can be placed in a continuum ranking from the lowest to the highest level of self-determination. At opposite ends of the continuum are the absence of motivation (amotivation) and intrinsic motivation. Between those ends there are four types of extrinsic motivation: external regulation, introjected regulation, identified regulation, and integrated regulation. Amotivation can be described as the absence of all consequences to people's behaviour. This absence leads to them having no intrinsic nor extrinsic motivation and they will drop the task as soon as there is an activity with a higher motivational value available.

Intrinsic motivation causes students to act for personal pleasure and satisfaction. It refers to the internal desire to do an action because the activity is fun and satisfying. Students are intrinsically motivated when they learn for the sole purpose of learning and consider this activity as interesting and challenging[4].

\subsection{Language Anxiety}

Foreign language anxiety as feelings of worry and negative emotional reactions that are generated when learning or using a second language [5]. Foreign language anxiety can be classified into three types: communication apprehension, fear of negative evaluation and test anxiety[6]. Horwitz, Horwitz and Cope (1986) developed a questionnaire consisting of 33 items, the Foreign Language Class Anxiety Scale (FLCAS), aimed at measuring language anxiety.

\subsection{Intended Effort (Intended Effort)}

Intended effort can be understood as the desire and intention of individuals to work, and spend energy and time on language learning activities[7].

As motivation is an antecedent of behaviour and only indirectly related to performance, intended effort is measured as an outcome variable in this study. As a more direct antecedent of performance than motivation itself, intended effort measures the magnitude of motivated behaviour as opposed to the direction which is defined as English learning in this study.

\subsection{Research questions}

1) What characterises high school students' motivation for learning English in South Bengkulu Regency?

2) What characterises student English language anxiety in South Bengkulu Regency?

3) Does the proposed model of the relationship between English learning motivation, English learning anxiety and intended effort adequately describe the data in the context of English learning in high school students in South Bengkulu Regency?

\section{Method}

\subsection{Population and sample}


The study sample are students who were and are still involved in the PPKBI program. The sampling technique used was non-probability convenience sampling.

\subsection{Measures and instruments}

The measurement instruments used in this study were as follows:

1) Language Learning Orientation Scale (LLOS). The LLOS has 21 items, arranged in 7 parameters, with each parameter consisting of 3 items[8].

2) Foreign Language Class Anxiety Scale (FLCAS). FLCAS has 33 items [6].

3) Intended Effort. The Intended Effort scale has 10 items[9].

\subsection{Procedure}

In the initial stage, reliability testing was carried out on the questionnaire by conducting a pilot study including 138 students (average age 16.41 years; 64 male). The research data set can be accessed in Open Science Framework [10].

After ensuring good reliability by method of item modification, an exploratory factor analysis (EFA) was conducted on LLOS and FLCAS to identify the main factors that had the highest influence on English learning. EFA was conducted using dataset of 453 high school students from South Bengkulu Regency (average age 16.15 years, 179 female).

Once the significant factors from each instrument were obtained, the reliability of the resulting new factors is assessed for each instrument.

In the next stage a confirmatory factor analysis (CFA) was carried out for each instrument, involving the common factors found in the EFA. Following this, the hypothesized model was modified, to obtain a model that met a satisfactory goodness-of-fit index. The research data set can be accessed in osf.io Open Science Framework.

\section{Results}

\subsection{Pilot Study}

FLCAS scale consisted of 33 items $(\alpha=.795)$, LLOS scale consisted of 21 items $(\alpha=$ $.795)$ and Intended Effort Scale consisted of 10 items $(\alpha=.848)$. As all values exceed 0.7 it can be concluded that all instruments used have an acceptable reliability value.

\subsection{Exploratory Factor Analysis}

Exploratory Factor Analysis (EFA) was conducted on the data of the main study, which consisted of 315 students. In the initial stage of the EFA, Principal Component Analysis (PCA) using the Keiser-Meyer-Olkin (KMO) test was performed independently for each instrument to determine the feasibility of the sample. The KMO tests obtained values of 0.774 and 0.857 for FLCAS and LLOS respectively, indicating that the sample selected for this study and the intended factor analysis have the potential to produce the best common factor. Bartlett's test of sphericity yielded significant results for FLCAS $(\chi 2=1815,475 \mathrm{df}=528$, $\mathrm{p}<.0001)$ and $\operatorname{LLOS}\left(\chi^{2}=1480.161, \mathrm{df}=210, \mathrm{p}<.0001\right)$ indicating that the sample used fulfilled the assumption of homoscedasticity. 
The factors chosen meet the condition of having Eigenvalues greater than one. The FLCAS instrument produced 10 factors, which explained cumulative variance of $56.5 \%$. The LLOS instrument produced 5 factors, with cumulative variance explained at $51.9 \%$.

Furthermore, to ensure that the factors are not correlated with each other, PCA is performed using oblique rotation, on a number of specific factors, 10 factors for FLCAS and 5 factors for LLOS, with a factor load value limit of 0.4 . Oblimin rotation was done based on the assumption of the existence of correlation between each factor.

All the factors of LLOS and FLCAS are orthogonal, becausethe correlations between each of the factors of LLOS and FLCAS are small. Therefore the EFA is continued by conducting a PCA using varimax rotation.

After extracting all the common factors, each common factor was tested for reliability. Items were added to each factor based on the magnitude of factor loading.In EFA results, FLCAS and LLOS have 2 and 5 common factors respectively.

\subsection{Structural Equation Modelling}

It is proposed that language learning motivation is influenced by language learning anxiety. This is based on the assumption that the more self-determined the motivation of a student is, the lower the level of anxiety he or she feels[8]. Since for anxiety only AnxF1 and AnxF2 with the alpha values, AnxF3 to AnxF10 are left out in the proposed model. Therefore, a direct path from language learning motivation to language learning anxiety is hypothesized. It is also proposed that motivation and anxiety in language learning are closely related to intended effort. Furthermore, a pathway of language learning motivation and anxiety to intended effort is expected.

A better goodness-of-fit value that fulfils the criteria of unidimensionality can be achieved by item modification.In addition to eliminating negative and small loading items, it is also necessary to identify correlations of items with each other. Items that show high correlations need to be eliminated. If there are multiple items correlating with each other the item with the lowest factor loading is taken out of the model first.

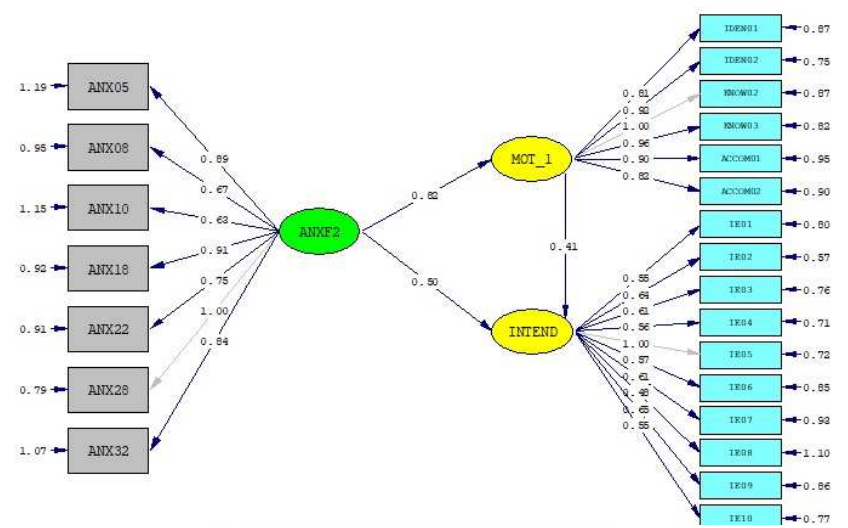

Figure 3.1. Final structural model of LLOS, FLCAS and Intended Effort

In CFA results, the model fit indices are acceptable $(\chi 2=521.11, \mathrm{df}=226, \mathrm{p}<.0001$, RSMEA $=0.052)$, hence the model can be considered as fit.

\subsection{Factor Loadings}


To answer the first and second research questions, the following table is given :

Table 3.1. The factor load table of each item on the ANXF2 and MOT1

\begin{tabular}{|c|c|c|c|c|}
\hline Item description & Load & $\begin{array}{c}\text { t- } \\
\text { value }\end{array}$ & $\begin{array}{l}\text { Err. } \\
\text { Var. }\end{array}$ & $\begin{array}{c}\text { Adj. } \\
\mathbf{R}^{2}\end{array}$ \\
\hline $\begin{array}{l}\text { I choose to be a person who can speak more than one language } \\
\text { (Iden01). }\end{array}$ & 0,81 & 8,64 & 0,87 & 0,27 \\
\hline I am sure English is important for self-development (Iden02). & 0,92 & 9,54 & 0,75 & 0,36 \\
\hline $\begin{array}{l}\text { I learn English for the satisfaction I get from knowing new things } \\
\text { (Know02). }\end{array}$ & 1,00 & 12,53 & 0,87 & 0,37 \\
\hline $\begin{array}{l}\text { I enjoy the feeling of gaining knowledge about English-speaking } \\
\text { countries / communities and how they live their lives (Know03). }\end{array}$ & 0,96 & 9,55 & 0,82 & 0,36 \\
\hline $\begin{array}{l}\text { I learn English for the pleasure I feel when I surpass myself in } \\
\text { English (Accom01). }\end{array}$ & 0,90 & 8,92 & 0,95 & 0,30 \\
\hline $\begin{array}{l}\text { I learn English for the pleasure I feel when I understand difficult } \\
\text { concepts of the English language (Accomp02). }\end{array}$ & 0,82 & 8,60 & 0,90 & 0,27 \\
\hline $\begin{array}{l}\text { It wouldn't bother me at all to take more English lessons / add } \\
\text { hours to my English lessons (ANX05). }\end{array}$ & 0,89 & 7,09 & 1,19 & 0,21 \\
\hline I am usually at ease during tests in my English class (ANX08) & 0,67 & 6,35 & 0,95 & 0,15 \\
\hline $\begin{array}{l}\text { I am worried about the consequences of failing my English class } \\
\text { (ANX10) }\end{array}$ & 0,63 & 5,69 & 1,15 & 0,12 \\
\hline I feel confident when I speak English in English class (ANX18) & 0,91 & 7,68 & 0,92 & 0,26 \\
\hline $\begin{array}{l}\text { I don't feel pressure to prepare very well for English class } \\
\text { (ANX22) }\end{array}$ & 0,75 & 6,93 & 0,91 & 0,19 \\
\hline $\begin{array}{l}\text { When I am on my way to english class, I feel very sure and relaxed } \\
\text { (ANX28) }\end{array}$ & 1,00 & 12,11 & 0,79 & 0,33 \\
\hline $\begin{array}{l}\text { I would probably feel comfortable around English native speakers } \\
\text { (ANX32) }\end{array}$ & 0,84 & 6,80 & 1,07 & 0,20 \\
\hline
\end{tabular}

\subsection{Multiple Regression Analysis}

Regarding the third question, multiple regression analysis is performed, with each coefficient values are given in the following table:

Tabel 3.2. Regression coefficient values on INTEND

\begin{tabular}{lccccc}
\hline & \multicolumn{4}{c}{ ANXF2 } & \multicolumn{2}{c}{ MOT_1 } \\
& $\boldsymbol{\beta}$ & $\mathbf{t}$ & $\boldsymbol{\beta}$ & $\mathbf{t}$ & Adj. $\mathbf{R}^{\mathbf{2}}$ \\
\hline INTEND & 0,50 & 2,47 & 0,41 & 2,41 & 0,24 \\
MOT_1 & 0,82 & 4,89 & & & 0,52 \\
& & & & & \\
\hline
\end{tabular}




\section{Discussion}

In regard to the first question, the items characterising students with a high motivation score and high intended effort score are: Iden01, Iden02, Know02, Know03, Accom01 and Accomp02.

In regard to the second research question, the following items were related to high intended effort: ANX05, ANX08, ANX10, ANX18, ANX22, ANX28 and ANX32.

In regards to the third question, the structural model revealed lower levels of anxiety are related to higher levels of motivation and a greater willingness to put effort into learning English. At the same time, higher motivation leads to more effort being made to learn English. Therefore, anxiety may have two pathways to influence student performance, first by inhibiting motivation, and second by lowering the learning effort. Further research is needed to establish the full impact of anxiety on English Language performance.

Further research can extend the number of participants involved in the study.

\section{References}

[1] Antara, "Indonesia peringkat 32 penguasaan Bahasa Inggris." [Online]. Available: https://www.antaranews.com/berita/600584/indonesia-level-32-mastery-language-english.

[2] Pedoman Bengkulu, "Bupati BS Resmikan Program Pembelajaran Komunitas Bahasa Inggris," 2017. [Online]. Available: http://pedomanbengkulu.com/2017/02/bupati-bs-resmikan-programpembelajaran-komunitas-bahasa-inggris. [Accessed: 05-Sep-2018].

[3] R. M. Ryan and E. L. Deci, "Self-Determination Theory and the Facilitation of Intrinsic Motivation, Social Development, and Well-Being," vol. 55, no. 1, pp. 68-78, 2000.

[4] M. E. Ehrman, B. Lou, and R. L. Oxford, "A brief overview of individual differences in second language learning 1," vol. 31, pp. 313-330, 2003.

[5] E. K. Horwitz, "Foreign and second language anxiety," vol. 43, no. 2, pp. 154-167, 2010.

[6] E. K. Horwitz, M. B. Horwitz, and J. Cope, "Foreign Language Classroom Anxiety Scale," Mod. Lang. J., vol. 70, no. 2, pp. 125-132, 1986.

[7] K. Csizér and Z. Dörnyei, "Language learners' motivational profiles and their motivated learning behavior," Lang. Learn., vol. 55, no. 4, pp. 613-659, 2005.

[8] K. A. Noels, L. G. Pelletier, R. Clément, and R. J. Vallerand, "Why Are You Learning a Second Language? Motivational Orientations and Self-Determination Theory," no. February, pp. $57-85,2000$.

[9] S. Safdari, "VALIDATION OF A TAILORED L2 MOTIVATIONAL SELF SYSTEM QUESTIONNAIRE THROUGH CONFIRMATORY FACTOR,” Int. Online J. Educ. Teach., vol. 4, no. 2, pp. 174-183, 2017.

[10] Y. P. Putra, "L2 Data Set," Open Science Framework, 2017. [Online]. Available: https://osf.io/wxgp6/?view_only=5a566921c21a436b88ed5111c681d71d. [Accessed: 05-Sep2018]. 